\title{
PENGUJIAN KAPASITAS LENTUR DAN KAPASITAS TUMPU KONSTRUKSI DINDING ALTERNATIF BERBAHAN DASAR EPOXY POLYSTYRENE (EPS)
}

\author{
Agus Setiawan \\ Jurusan Teknik Sipil, Fakultas Sains dan Teknologi, Universitas Bina Nusantara \\ Jln. K.H. Syahdan No. 9, Palmerah, Jakarta Barat 11480 \\ agustinusset@yahoo.com
}

\begin{abstract}
This research has an objective to investigate the capacity of alternative wall panel construction, with EPS (Epoxy Polystyrene) as a based material. EPS with $5 \mathrm{~cm}$ of thickness and $1 \mathrm{~m}$ of width used as specimens at this research. The specimens reinforced with wire mesh $(\phi 4-150 \mathrm{~mm})$ both sides, and finished by mortar cement with 1,5 and $3 \mathrm{~cm}$ of thickness. Each specimen was tested in the laboratory to obtain their flexural capacity and bearing capacity. Specimen with $8,5 \mathrm{~cm}$ of thickness has $150 \mathrm{~kg} / \mathrm{m}^{2}$ of flexural capacity, while specimen with $11 \mathrm{~cm}$ of thickness has $450 \mathrm{~kg} / \mathrm{m}^{2}$ of flexural capacity. Alternative wall panel with EPS, can be used as a bearing wall, with 2,9 tons/m of bearing capacity.
\end{abstract}

Keywords: Epoxy Polystyrene, wire mesh, flexural capacity, bearing capacity

\begin{abstract}
ABSTRAK
Penelitian ini bertujuan untuk menyelidiki kapasitas dari kontruksi panel dinding alternative, dengan menggunakan Epoxy Polystyrene (EPS) sebagai bahan dasar. Panel EPS yang digunakan dalam penelitian ini memiliki ketebalan $5 \mathrm{~cm}$ dengan lebar $1 \mathrm{~m}$. Benda uji panel EPS diberi tulangan wire mesh ( $\phi 4-150 \mathrm{~mm}) \mathrm{di}$ kedua sisinya, dan selanjutnya diberi lapis finishing dari mortar semen setebal 1,5 dan $3 \mathrm{~cm}$. Tiap benda uji diuji di laboratorium untuk memperoleh kapasitas lentur dan kapasitas tumpu dari panel dinding alternative tersebut. Benda uji dengan ketebalan 8,5 cm memiliki kapasitas lentur sebesar $150 \mathrm{~kg} / \mathrm{cm}^{2}$, sedangkan benda uji dengan tebal $11 \mathrm{~cm}$ memiliki kapasitas lentur sebesar $450 \mathrm{~kg} / \mathrm{cm}^{2}$. Dari hasil pengujian kapasitas geser diperoleh hasil bahwa panel dinding alternatif ini dapat digunakan sebagai dinding penumpu dengan kapasitas tumpu sebesar 2,9 ton $/ \mathrm{m}$.
\end{abstract}

Kata kunci: Epoxy Polystyrene, wire mesh, kapasitas lentur, kapasitas tumpu 


\section{PENDAHULUAN}

Perkembangan jenis dan bahan baku material bangunan mengalami perkembangan yang cukup pesat. EPS yang dikenal masyarakat luas sebagai styrofoam, semula hanya dimanfaatkan di bidang seni namun kini mulai memegang peran di bidang material bangunan. EPS sebagai bahan bangunan alternatif sudah mulai digunakan dalam berbagai bidang konstruksi, mulai dari konstruksi jalan raya, bendungan, hingga sebagai dinding bangunan. Selain ringan, mudah dan cepat dalam pelaksanaan konstruksinya, bahan EPS juga mudah dibentuk sesuai keinginan pengguna. Tuntutan yang tinggi terhadap penyediaan fasilitas perumahan sederhana di Indonesia, membuat pihak pengembang perumahan mencari alternatif bahan bangunan yang mudah dikonstruksikan dan murah, namun aspek kekuatan/kualitas bahan tentunya tidak dapat diabaikan begitu saja.

Pelaku konstruksi di Indonesia juga mulai mengembangkan penggunaan EPS sebagai bahan alternatif dalam pembuatan konstruksi dinding. Waktu pengerjaan yang cepat, dan berat yang relatif ringan menjadi salah satu keandalan konstruksi dinding EPS ini. Namun konstruksi dinding ini belumlah terstandarkan secara resmi, sehingga harus dilakukan serangkaian percobaan untuk menguji kekuatan material. Tujuan dari penelitian ini adalah untuk menentukan intensitas beban lentur dan intensitas beban tumpu maksimum yang dapat dipikul oleh suatu panel dinding EPS.

\section{METODE}

Panel dinding alternatif secara umum tersusun dari panel epoxy polystyrene (EPS) yang dirangkai dengan jaring kawat baja (wire mesh) di kedua sisinya dan kemudian diberi lapis finishing berupa plesteran yang terdiri dari campuran antara pasir dan semen dalam suatu perbandingan tertentu. Dalam uraian berikut dijelaskan tentang bahan atau benda uji yang akan digunakan dalam penelitian ini serta langkah atau metode pengujian yang dilakukan, meliputi pengujian kapasitas lentur dan pengujian kapasitas tumpu dari panel dinding alternatif berbahan dasar epoxy polystyrene.

Gambar 1 menunjukan panel tipikal dengan tebal insulasi 40 mm s.d 150 mm, tebal satu lapis plesteran antara $40 \mathrm{~mm}$ s.d $50 \mathrm{~mm}$ sehingga ketebalan panel dinding keseluruhan adalah $120 \mathrm{~mm}$ s.d $250 \mathrm{~mm}$. Tebal insulasi dan plesteran bertulang tergantung pada insulasi panas dan kapasitas struktur yang diperlukan. Kekuatan dan kekakuan panel tiga dimensi ini dicapai melalui kawat baja silang yang dilas ke kedua sisi jaring kawat baja las pabrikan. Susunan jaring kawat baja tiga dimensi tersebut akan berperilaku komposit penuh dalam hal kekakuan dan menyalurkan gaya geser.

\section{Benda Uji}

Benda uji yang digunakan dalam penelitian ini adalah berupa panel dinding, yang dibuat dari bahan EPS setebal $5 \mathrm{~cm}$. Kedua sisi dinding diberi lapisan tulangan besi berdiameter $4 \mathrm{~mm}$ yang dipasang pada keseluruhan permukaan dinding dengan jarak antar tulangan sebesar $150 \mathrm{~mm}$. Kedua lapis tulangan pada kedua sisi dinding dihubungkan dengan sejumlah stek tulangan yang berdiameter $4 \mathrm{~mm}$ dan diikatkan dengan kawat bendrat. Setelah lapis tulangan terpasang secara sempurna pada kedua sisi panel EPS, maka selanjutnya dilakukan proses finishing pada kedua sisi panel tersebut dengan pemberian plesteran dan acian setebal $2-3 \mathrm{~cm}$ yang merupakan campuran antara semen Portland (PC) dengan pasir dalam perbandingan $1: 4$. 


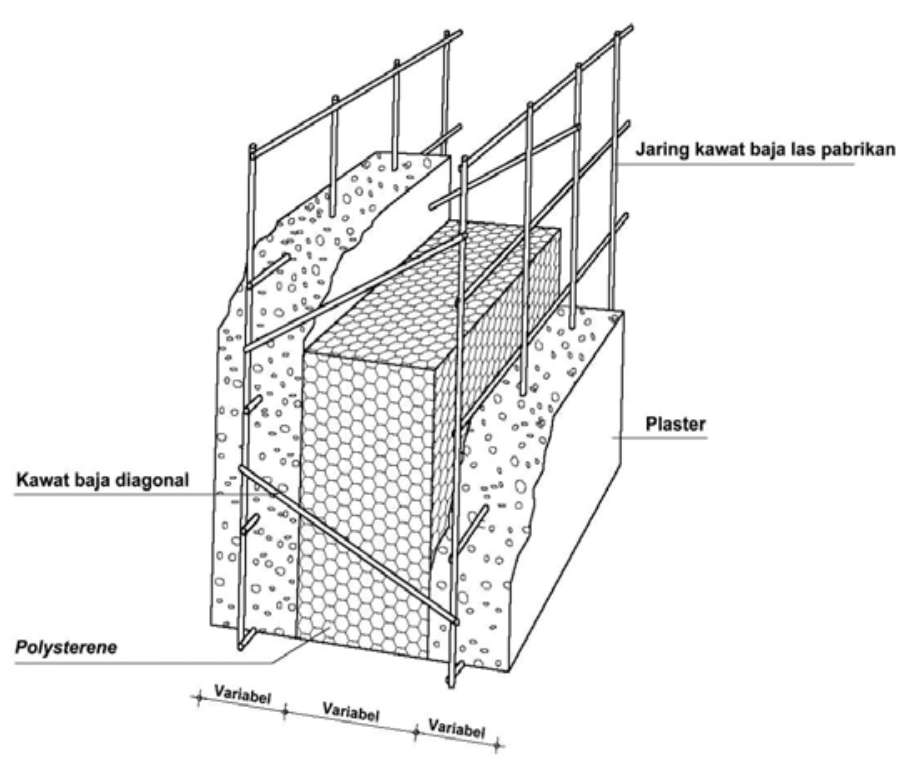

Gambar 1 Penampang Panel Dinding Alternatif Berbahan Dasar EPS

\section{Pengujian Kapasitas Lentur}

Benda uji panel dinding EPS diletakkan pada dua tumpuan secara horizontal, seperti pada gambar 2. Beban ditambahkan secara bertahap di atas benda uji, dengan menggunakan kubus - kubus beton dan air. Penambahan beban dilakukan bertahap setiap interval $100 \mathrm{~kg} / \mathrm{m}^{2}$, setiap penambahan beban, besar lendutan di tengah bentang dicatat setiap interval waktu 15 menit selama 1 jam. Pada beban puncak, beban ditahan selama 24 jam, dan lendutan maksimum dibaca keesokan harinya. Pelepasan beban juga dilakukan secara bertahap, dan lendutan yang terjadi selama pelepasan beban tetap dicatat.

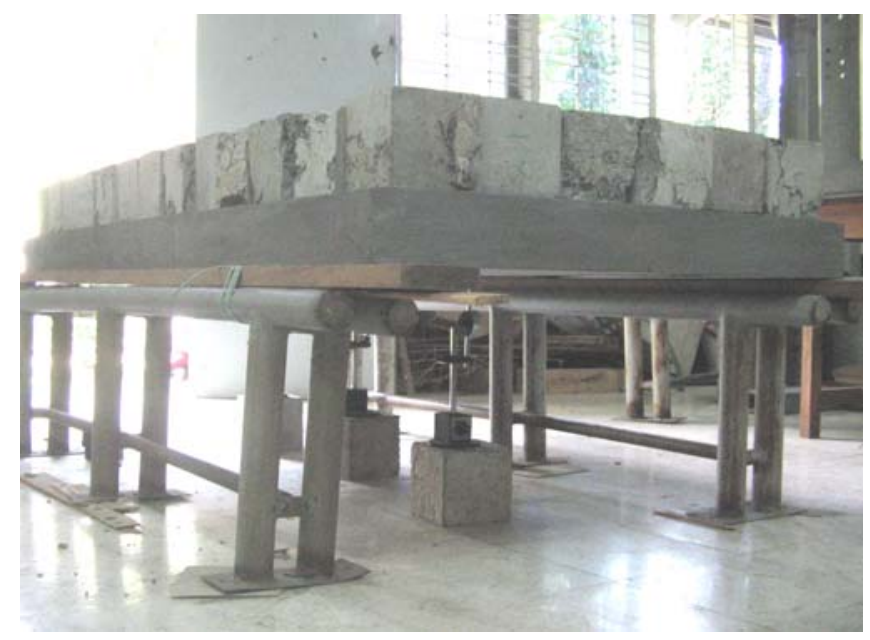

Gambar 2 Posisi Pengujian Kapasitas Lentur Dinding EPS

\section{Pengujian Kapasitas Tumpu}

Benda uji panel dinding EPS diletakkan pada loading frame dalam arah vertikal. Selanjutnya di sisi atas benda uji diberi tumpukan kayu yang berfungsi untuk meratakan beban dari hydraulic jack. Hydraulic jack dipasang pada sisi atas benda uji tepat di tengah bentang. Selanjutnya beban mulai 
diberikan pada benda uji melalui penekanan oleh hydraulic jack, besar beban dapat dibaca pada manometer yang ada. Besar deformasi dalam arah lateral terbaca melalui dial gauge yang dipasang. Pembebanan dihentikan ketika benda uji mulai mengalami keruntuhan/retak.

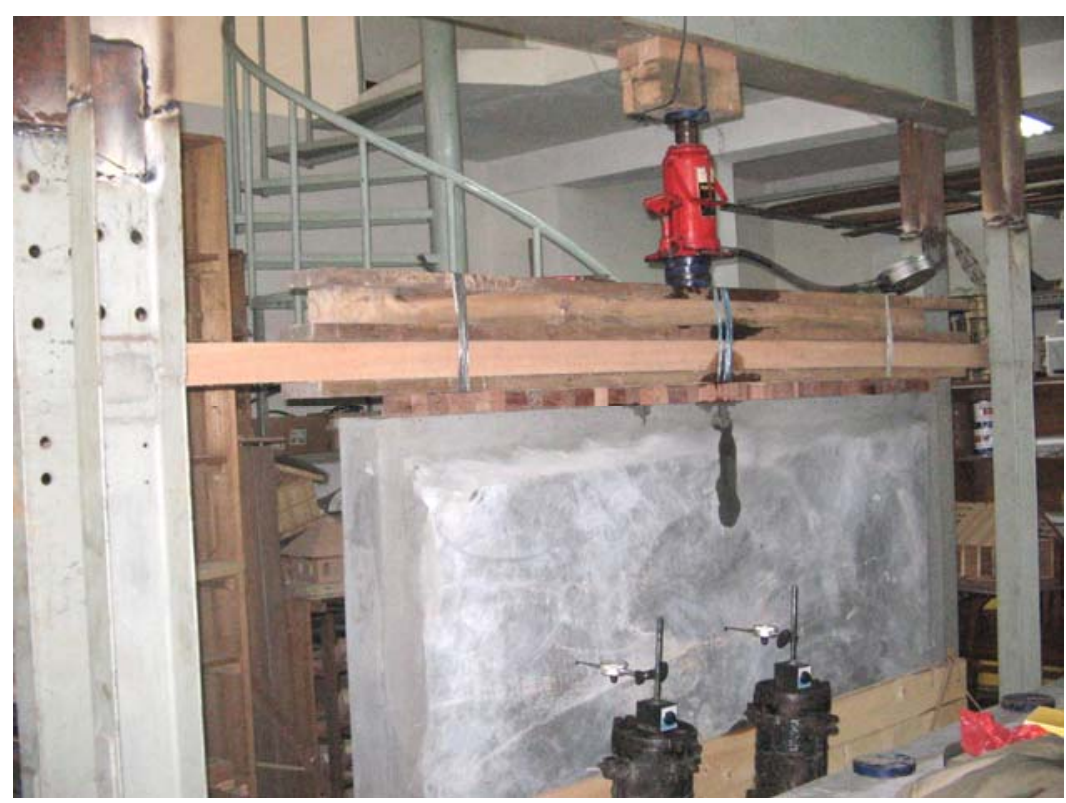

Gambar 3 Posisi Pengujian Kapasitas Tumpu Dinding EPS

\section{HASIL DAN PEMBAHASAN}

\section{Pengujian Kapasitas Lentur Dinding EPS}

Hasil pengujian kapasitas lentur panel dinding EPS disajikan dalam tabel 1 dan 2, masing masing untuk ketebalan dinding 8,5 cm dan $11 \mathrm{~cm}$. Selanjutnya Gambar 3 dan 4 menunjukkan korelasi antara beban uji dengan lendutan yang terjadi pada panel dinding EPS, untuk tebal dinding 8,5 cm dan $11 \mathrm{~cm}$.

Kedua kurva uji pembebanan pada gambar 3 dan 4 menunjukkan bahwa lendutan pelat tidak kembali pada posisi semula (nol) setelah dilakukan pelepasan beban (rebound), hal ini mengindikasikan bahwa pelat telah dibebani hingga batas plastisnya.

Acuan lendutan ijin yang diperbolehkan untuk memenuhi syarat serviceability suatu konstruksi pelat diambil dari SNI 03-2847-2002 "Tata Cara Perhitungan Struktur Beton Untuk Bangunan Gedung” Ps. 11.5(2(6)), yang menyatakan bahwa lendutan seketika akibat beban hidup (L) tidak boleh melampaui $\lambda / 360$, dengan $\lambda$ adalah bentang pelat bersangkutan. Dengan mengingat bahwa bentang pelat uji adalah $1,00 \mathrm{~m}$ ( $=1000 \mathrm{~mm}$ ), maka lendutan ijin maksimum adalah sebesar 1000/360 $\approx 2,75 \mathrm{~mm}$.

Selanjutnya dari gambar 4 dan 5 terlihat hasil pada lendutan $2,75 \mathrm{~mm}$, beban maksimum yang dapat dipikul oleh kedua pelat adalah $350 \mathrm{~kg} / \mathrm{m}^{2}$ untuk pelat dengan tebal $8,5 \mathrm{~cm}$ dan $850 \mathrm{~kg} / \mathrm{m}^{2}$ untuk pelat dengan tebal $11 \mathrm{~cm}$. Dengan mengasumsikan beban mati tambahan yang bekerja adalah sebesar $100 \mathrm{~kg} / \mathrm{m}^{2}$, serta mengingat faktor beban yang disyaratkan dalam SNI untuk beban mati sebesar 1,2 dan beban hidup sebesar 1,6, maka dapat direkomendasikan hal - hal berikut, untuk pelat 8,5 cm 
hanya dapat memikul beban hidup sebesar $150 \mathbf{~ k g} / \mathbf{m}^{2}$, sedangkan untuk pelat dengan ketebalan $11 \mathrm{~cm}$ dapat memikul beban hidup sebesar $450 \mathrm{~kg} / \mathbf{m}^{2}$.
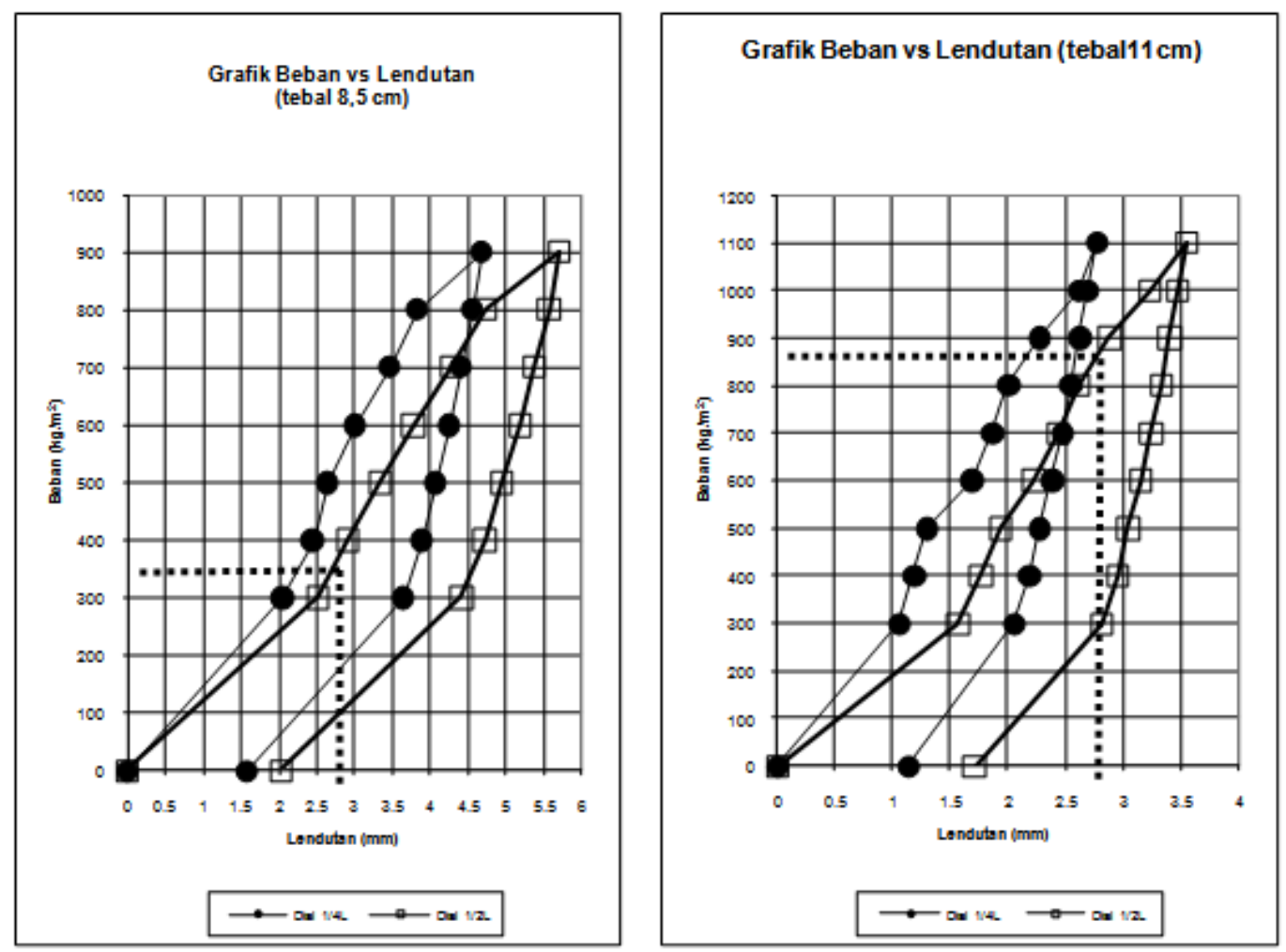

Gambar 4 Kurva Beban vs Lendutan $(\mathrm{t}=8,5 \mathrm{~cm}) \quad$ Gambar 5 Kurva Beban vs Lendutan $(\mathrm{t}=11 \mathrm{~cm})$

Tabel 1 Hasil Loading Test Pelat EPS Tebal 8,5 cm

\begin{tabular}{|c|c|c|c|c|c|}
\hline \multirow{2}{*}{ No } & \multirow{2}{*}{$\begin{array}{c}\text { Beban Uji } \\
\left(\mathrm{kg} / \mathrm{m}^{2}\right)\end{array}$} & \multirow{2}{*}{$\begin{array}{l}\text { Durasi Beban } \\
\text { (menit) }\end{array}$} & \multirow[b]{2}{*}{ Jam Ke } & \multicolumn{2}{|c|}{ Bacaan Dial ( x 0.01 mm) } \\
\hline & & & & 1/4 bentang & $1 / 2$ bentang \\
\hline 1 & 0 & 0 & 0 & 0 & 0 \\
\hline \multirow{4}{*}{2} & \multirow{4}{*}{300} & $15^{\prime}$ & 0,25 & 202 & 248 \\
\hline & & $30^{\prime}$ & 0,5 & 203 & 249 \\
\hline & & $45^{\prime}$ & 0,75 & 205 & 251 \\
\hline & & $60^{\prime}$ & 1 & 205 & 252 \\
\hline \multirow{4}{*}{3} & \multirow{4}{*}{400} & $15^{\prime}$ & 1,25 & 230 & 286 \\
\hline & & $30^{\prime}$ & 1,5 & 233 & 290 \\
\hline & & $45^{\prime}$ & 1,75 & 234 & 291 \\
\hline & & $60^{\prime}$ & 2 & 245 & 292 \\
\hline \multirow{4}{*}{4} & \multirow{4}{*}{500} & $15^{\prime}$ & 2,25 & 257 & 324 \\
\hline & & $30^{\prime}$ & 2,5 & 261 & 329 \\
\hline & & $45^{\prime}$ & 2,75 & 263 & 331 \\
\hline & & $60^{\prime}$ & 3 & 265 & 333 \\
\hline \multirow{4}{*}{5} & \multirow{4}{*}{600} & $15^{\prime}$ & 3,25 & 294 & 371 \\
\hline & & $30^{\prime}$ & 3,5 & 299 & 375 \\
\hline & & $45^{\prime}$ & 3,75 & 300 & 377 \\
\hline & & $60^{\prime}$ & 4 & 301 & 378 \\
\hline \multirow{2}{*}{6} & \multirow{2}{*}{700} & $15^{\prime}$ & 4,25 & 338 & 416 \\
\hline & & $30^{\prime}$ & 4,5 & 343 & 420 \\
\hline
\end{tabular}




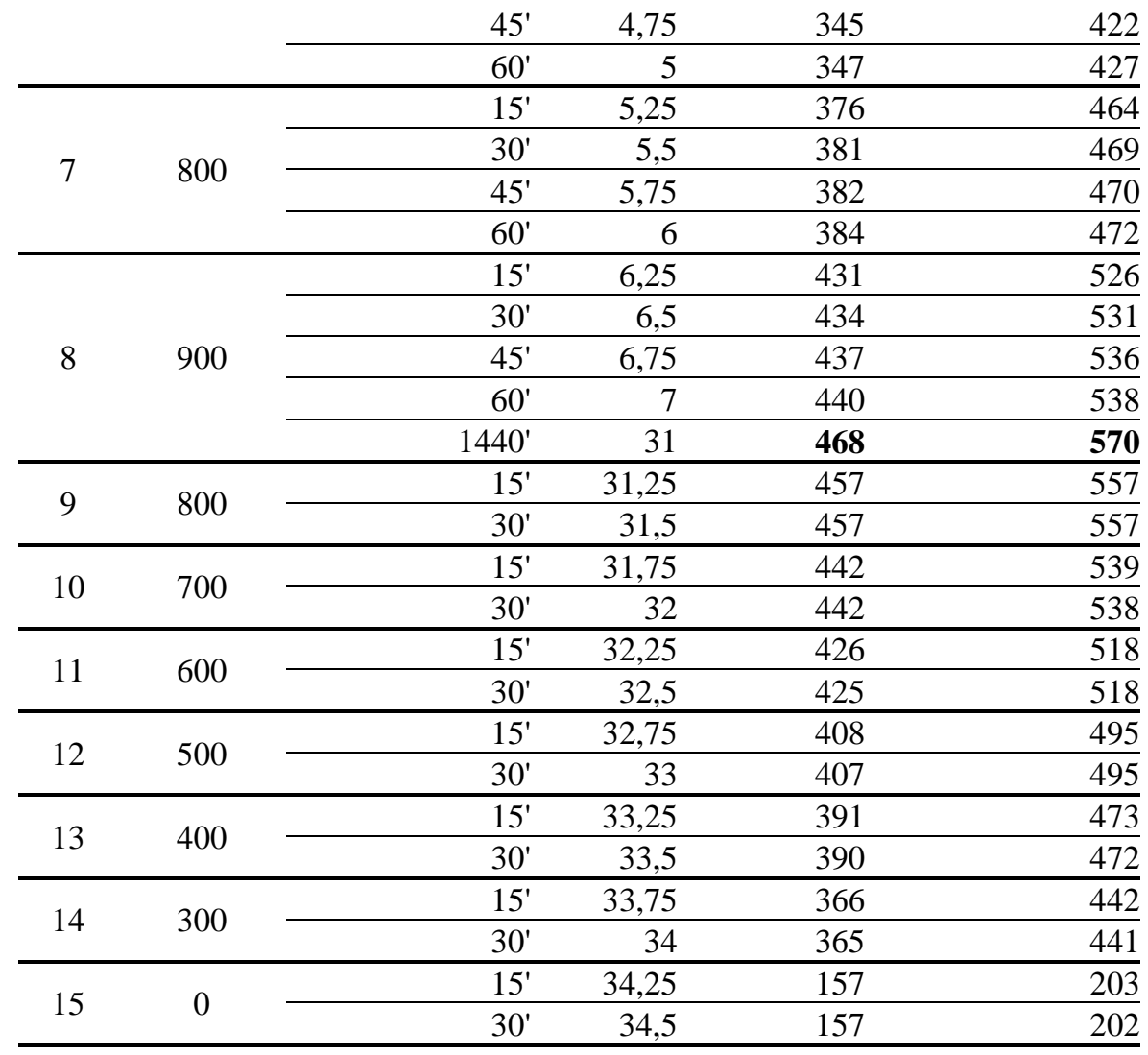

Tabel 2 Hasil Loading Test Pelat EPS Tebal $11 \mathrm{~cm}$

\begin{tabular}{|c|c|c|c|c|c|}
\hline \multirow{2}{*}{ No } & \multirow{2}{*}{$\begin{array}{c}\text { Beban Uji } \\
\left(\mathrm{kg} / \mathrm{m}^{2}\right)\end{array}$} & \multirow{2}{*}{$\begin{array}{c}\text { Durasi Beban } \\
\text { (menit) }\end{array}$} & \multirow{2}{*}{ Jam Ke } & \multicolumn{2}{|c|}{ Bacaan Dial ( x 0.01 mm) } \\
\hline & & & & $1 / 4$ bentang & $1 / 2$ bentang \\
\hline 1 & 0 & 0 & 0 & 0 & 0 \\
\hline \multirow{4}{*}{2} & \multirow{4}{*}{300} & $15^{\prime}$ & 0,25 & 104 & 152 \\
\hline & & $30^{\prime}$ & 0,5 & 106 & 156 \\
\hline & & $45^{\prime}$ & 0,75 & 106 & 156 \\
\hline & & $60^{\prime}$ & 1 & 106 & 157 \\
\hline \multirow{4}{*}{3} & \multirow{4}{*}{400} & $15^{\prime}$ & 1,25 & 117 & 172 \\
\hline & & $30^{\prime}$ & 1,5 & 118 & 175 \\
\hline & & $45^{\prime}$ & 1,75 & 119 & 176 \\
\hline & & $60^{\prime}$ & 2 & 119 & 177 \\
\hline \multirow{4}{*}{4} & \multirow{4}{*}{500} & $15^{\prime}$ & 2,25 & 127 & 190 \\
\hline & & $30^{\prime}$ & 2,5 & 129 & 191 \\
\hline & & $45^{\prime}$ & 2,75 & 129 & 192 \\
\hline & & $60^{\prime}$ & 3 & 130 & 194 \\
\hline \multirow{4}{*}{5} & \multirow{4}{*}{600} & $15^{\prime}$ & 3,25 & 165 & 219 \\
\hline & & $30^{\prime}$ & 3,5 & 167 & 221 \\
\hline & & $45^{\prime}$ & 3,75 & 168 & 222 \\
\hline & & $60^{\prime}$ & 4 & 169 & 223 \\
\hline \multirow{4}{*}{6} & \multirow{4}{*}{700} & $15^{\prime}$ & 4,25 & 184 & 241 \\
\hline & & $30^{\prime}$ & 4,5 & 186 & 243 \\
\hline & & $45^{\prime}$ & 4,75 & 186 & 244 \\
\hline & & $60^{\prime}$ & 5 & 187 & 244 \\
\hline \multirow{3}{*}{7} & \multirow{3}{*}{800} & $15^{\prime}$ & 5,25 & 199 & 258 \\
\hline & & $30^{\prime}$ & 5,5 & 200 & 260 \\
\hline & & $45^{\prime}$ & 5,75 & 201 & 261 \\
\hline
\end{tabular}




\begin{tabular}{|c|c|c|c|c|c|}
\hline & & $60^{\prime}$ & 6 & 201 & 262 \\
\hline \multirow{4}{*}{8} & \multirow{4}{*}{900} & $15^{\prime}$ & 6,25 & 225 & 284 \\
\hline & & $30^{\prime}$ & 6,5 & 227 & 286 \\
\hline & & $45^{\prime}$ & 6,75 & 228 & 288 \\
\hline & & $60^{\prime}$ & 7 & 228 & 289 \\
\hline \multirow{4}{*}{9} & \multirow{4}{*}{1000} & $15^{\prime}$ & 7,25 & 261 & 323 \\
\hline & & $30^{\prime}$ & 7,5 & 261 & 324 \\
\hline & & $45^{\prime}$ & 7,75 & 262 & 324 \\
\hline & & $60^{\prime}$ & 8 & 262 & 324 \\
\hline \multirow{5}{*}{10} & \multirow{5}{*}{1100} & $15^{\prime}$ & 8,25 & 273 & 336 \\
\hline & & $30^{\prime}$ & 8,5 & 273 & 337 \\
\hline & & $45^{\prime}$ & 8,75 & 274 & 338 \\
\hline & & $60^{\prime}$ & 9 & 274 & 338 \\
\hline & & $1440^{\prime}$ & 33 & 278 & 356 \\
\hline \multirow{2}{*}{9} & \multirow{2}{*}{1000} & $15^{\prime}$ & 33,25 & 270 & 349 \\
\hline & & $30^{\prime}$ & 33,5 & 270 & 348 \\
\hline \multirow{2}{*}{10} & \multirow{2}{*}{900} & $15^{\prime}$ & 33,75 & 264 & 342 \\
\hline & & $30^{\prime}$ & 34 & 263 & 341 \\
\hline \multirow{2}{*}{11} & \multirow{2}{*}{800} & $15^{\prime}$ & 34,25 & 256 & 334 \\
\hline & & $30^{\prime}$ & 34,5 & 255 & 334 \\
\hline \multirow{2}{*}{12} & \multirow{2}{*}{700} & $15^{\prime}$ & 34,75 & 248 & 326 \\
\hline & & $30^{\prime}$ & 35 & 248 & 325 \\
\hline \multirow{2}{*}{13} & \multirow{2}{*}{600} & $15^{\prime}$ & 35,25 & 240 & 317 \\
\hline & & $30^{\prime}$ & 35,5 & 239 & 316 \\
\hline \multirow{2}{*}{14} & \multirow{2}{*}{500} & $15^{\prime}$ & 35,75 & 229 & 306 \\
\hline & & $30^{\prime}$ & 36 & 228 & 305 \\
\hline \multirow{2}{*}{15} & \multirow{2}{*}{400} & $15^{\prime}$ & 36,25 & 219 & 297 \\
\hline & & $30^{\prime}$ & 36,5 & 219 & 296 \\
\hline \multirow{2}{*}{16} & \multirow{2}{*}{300} & $15^{\prime}$ & 36,75 & 206 & 282 \\
\hline & & $30^{\prime}$ & 37 & 206 & 282 \\
\hline \multirow{2}{*}{17} & \multirow{2}{*}{0} & $15^{\prime}$ & 37,25 & 114 & 171 \\
\hline & & $30^{\prime}$ & 37,5 & 114 & 171 \\
\hline
\end{tabular}

\section{Pengujian Kapasitas Tumpu Dinding EPS}

Hasil pengujian kapasitas tumpu panel dinding EPS disajikan dalam tabel 3. Selanjutnya Gambar 6 menunjukkan korelasi antara beban uji dengan lendutan yang terjadi pada panel dinding EPS, untuk tebal dinding $8,5 \mathrm{~cm}$ dan $11 \mathrm{~cm}$.

Tabel 3 Hasil Uji Kapasitas Tumpu Konstruksi Dinding EPS

\begin{tabular}{cccc}
\hline \multirow{2}{*}{ No } & Beban & \multicolumn{2}{c}{ Bacaan Dial $\mathbf{( x 0 . 0 1 ~} \mathbf{~ m m})$} \\
\cline { 2 - 4 } & $\mathbf{( \mathbf { k g } / \mathbf { c m } ^ { 2 } )}$ & $\mathbf{t}=\mathbf{8 , 5} \mathbf{~ c m}$ & $\mathbf{t = 1 1} \mathbf{~ c m}$ \\
\hline 1 & 0 & 0 & 0 \\
\hline 2 & 50 & 0,3 & 3,8 \\
\hline 3 & 75 & 0,65 & 4,15 \\
\hline 4 & 100 & 0,97 & 4,5 \\
\hline 5 & 125 & 1,32 & 5,05 \\
\hline 6 & 150 & 1,8 & 5,6 \\
\hline 7 & 175 & 2,31 & 5,925 \\
\hline 8 & 200 & 2,85 & 6,25 \\
\hline 9 & 225 & 3,21 & 6,575 \\
\hline
\end{tabular}




\begin{tabular}{cccc}
10 & 250 & 3,71 & 6,9 \\
\hline 11 & 275 & & 7,25 \\
\hline
\end{tabular}

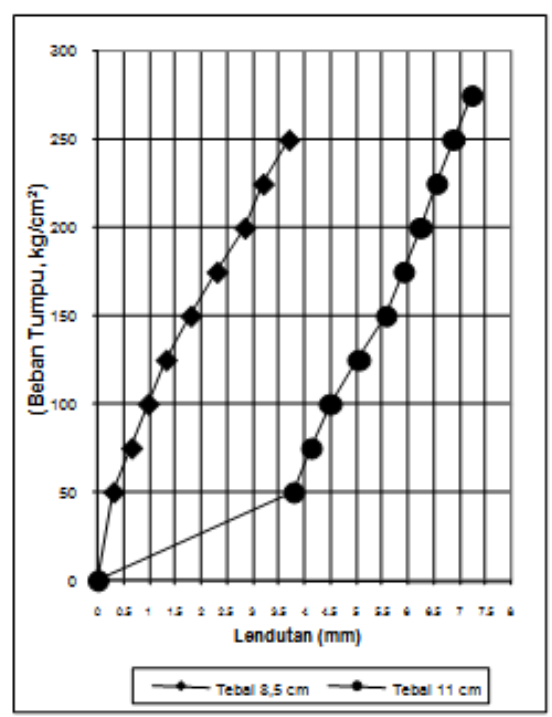

\section{Gambar 6 Hasil Uji Kapasitas Tumpu}

Dari hasil pengujian diperoleh data bahwa untuk dinding EPS tebal $8,5 \mathrm{~cm}$, telah terjadi retakan pada benda uji saat beban menunjukkan angka $250 \mathrm{~kg} / \mathrm{cm}^{2}$. Sedangkan pada benda uji dinding EPS tebal $11 \mathrm{~cm}$ diperoleh deformasi yang hampir 10 kali lipat lebih besar dari dinding tebal $8,5 \mathrm{~cm}$ (pada beban $50 \mathrm{~kg} / \mathrm{cm} 2$ ), sehingga dalam analisa selanjutnya akan didasarkan pada benda uji pertama saja dengan ketebalan $8,5 \mathrm{~cm}$.

Beban maksimum yang dapat dipikul dinding EPS adalah $250 \mathrm{~kg} / \mathrm{cm}^{2}$, dengan memperhitungkan luas penampang dongkrak hidrolik sebesar 22,9 $\mathrm{cm}^{2}$, maka diperoleh beban uji sebesar $5725 \mathrm{~kg}$. Beban tambahan lain berupa perata beban dari kayu sebesar $100 \mathrm{~kg}$. Sehingga total beban tumpu yang dipikul oleh dinding EPS adalah sebesar $5825 \mathrm{~kg}$, atau setara dengan beban merata $2900 \mathrm{~kg} / \mathrm{m}$.

Dengan mengasumsikan bahwa suatu konstruksi rumah sederhana bertingkat dua dengan menggunakan pelat lantai EPS pula, maka dapat dihitung bahwa total beban ultimit yang harus dipikul oleh suatu dinding EPS adalah sebesar $900 \mathrm{~kg} / \mathrm{m}$ (untuk modul pelat ukuran $2 \times 2 \mathrm{~m}^{2}$ ). Perhitungannya adalah sebagai berikut:

Beban layan yang harus dipikul :

Berat sendiri pelat EPS (tebal $11 \mathrm{~cm}$ ) $=130 \mathrm{~kg} / \mathrm{m}^{2}$

Beban mati tambahan (plafond, keramik dll) $=100 \mathrm{~kg} / \mathrm{m}^{2}$

Beban hidup rumah tinggal

$$
=250 \mathrm{~kg} / \mathrm{m}^{2}
$$

$$
\mathrm{q}_{\mathrm{u}}=1,2(130+100)+1,6(250)=676 \mathrm{~kg} / \mathrm{m}^{2}
$$

Beban maksimum yang harus dipikul oleh konstruksi dinding EPS (interior panel) $=2 \times 676 \times 2 / 3 \approx$ $900 \mathrm{~kg} / \mathrm{m}$ 


\section{PENUTUP}

Beberapa simpulan yang dapat diambil dari hasil penelitian yang telah dilakukan, adalah (1) pelat EPS dengan tebal 8,5 cm (lebar $1 \mathrm{~m}$ ) mampu memikul beban layan sebesar $150 \mathrm{~kg} / \mathrm{m}^{2}$; (2) pelat EPS dengan tebal $11 \mathrm{~cm}$ (lebar 1m) mampu memikul beban layan sebesar $450 \mathrm{~kg} / \mathrm{m}^{2}$; (3) konstruksi dinding EPS ternyata dapat digunakan sebagai dinding struktural (sebagai bearing wall) dengan kemampuan memikul beban tumpu ultimit sebesar $2900 \mathrm{~kg} / \mathrm{m}$.

Saran yang dapat diberikan dalam masalah pemakaian konstruksi pelat atau dinding EPS, antara lain (1) pelat EPS dengan ketebalan $11 \mathrm{~cm}$ mampu digunakan sebagai konstruksi pelat lantai pada bangunan rumah tinggal dua lantai sederhana, namun untuk bentang besar masih perlu dilakukan pengujian beban (loading test) dalam skala penuh di lapangan; (2) dinding EPS dengan tebal 8,5 cm layak diperhitungkan sebagai dinding struktural, yang mampu berkontribusi membantu kolom struktur dalam distribusi beban layan yang bekerja. Namun dinding dengan ketebalan $11 \mathrm{~cm}$ perlu dipertimbangkan untuk mengingat aspek durabilitas material; (3) masih perlu diuji kapasitas geser dinding EPS dalam kapasitasnya untuk memikul beban gempa, sehingga diharapkan dapat menjadi konstruki dinding alternatif yang tahan gempa.

\section{DAFTAR PUSTAKA}

Badan Standarisasi Nasional. (2008). Tata Cara Perencanaan dan Pelaksanaan Bangunan Gedung Menggunakan Panel Jaring Kawat Baja Tiga Dimensi (PJKB-3D) Las Pabrikan, SNI 7392.2008, Bandung: Departemen Permukiman dan Prasarana Wilayah.

Badan Standarisasi Nasional. (2002). Tata Cara Perhitungan Struktur Beton, SNI 03-28467-2002, Bandung: Departemen Permukiman dan Prasarana Wilayah.

Cormack, J. C. (2004). Desain Beton Bertulang. Jakarta: Erlangga.

Hasooun, M. N., \& Manaseer, A. A. (2005). Structure Concrete Theory and Design, Canada: John Wiley \& Sons Inc.

Nawy, E. G. (2005). Reinforced Concrete a Fundamental Approach. New Jersey: Pearson Education Inc.

Nilson, A. H., Darwin, D., \& Dolan, C. W. (2003). Design of Concrete Structures, New York: Mc Graw Hill. 